\title{
November/December 2017
}

\author{
Daniel J. Mahoney ${ }^{1}$
}

Published online: 16 October 2017

(C) Springer Science+Business Media, LLC 2017

\section{Peter Augustine Lawler (1951-2017)}

Daniel J. Mahoney, Senior Editor and Book Review Editor writes:

Peter Augustine Lawler (1951-2017) was one of the most impressive political theorists and social critics of his generation. An acclaimed professor for 38 years at Berry College in Rome, Georgia, he was a former member of President George W. Bush's Bioethics Council, and the longtime editor of Perspectives on Political Science. In the months before his death he had assumed the editorship at Modern Age, the distinguished conservative intellectual quarterly, and gave every indication that that journal would now be truly indispensable reading. He also blogged for First Things and National Review on politics, political thought, and popular culture, and had a loyal readership in both forums. A philosophical conservative, he was not prone to polemics and practiced the intellectual virtue of equity or fair-mindedness. In commenting on day-to-day events he never lost sight of eternity or enduring human nature. He was remarkably genial and the best of company. He was also a faithful friend of Society and published no less than seventeen articles in the journal between 2000 and 2016. I have examined Peter's life and work as a whole in the summer 2017 issue of the Claremont Review of Books. In this brief tribute, I would like to highlight the distinctive voice and perspective that Peter Augustine Lawler brought to Society over the years.

His was a humane and urbane conservatism, neither populist nor elitist in character, eschewing both nastiness and pusillanimity. As a political theorist and social critic who was neither libertarian nor statist in orientation, Peter drew on the best resources of reason and revelation to present and defend a rich philosophical anthropology that did justice to reason in the most capacious sense of the term. He was a partisan of the soul in an age drifting toward pantheism and philosophical materialism. At the same time, as an intellectually penetrating Catholic, he had no time of day for fideism, or the rejection of human reason within its legitimate sphere.

Reviewing six of Peter's most suggestive articles for Society, one comes across some recurring and always penetrating themes. He was profoundly skeptical of the libertarian drift in our culture ("Libertarian Fantasy and Statist Reality," November/ December 2002). He worried about a "designer" future when science manipulated bodies and souls and government coerced in the name of "human enhancement." Libertarian fantasies, he feared, would lead to statist intervention in the intimate lives of human beings. Peter was convinced that human beings are not gods, that there are limits to "moral autonomy," and that loyalty to friends, family, and country are at least as important to a life well lived as individual consent. Peter has even been called a "thanocentric" political theorist, one who took his bearings from the immortal soul. He loved life but believed that human beings needed to learn to die well. Marx, undoubtedly a great social theorist, nonetheless was terribly mistaken in repudiating the various goods ("religion, love, virtue, political life, and so forth") that "human beings have always had to live well enough with death" ("Communism Today," May/June 2004). Communism was totalitarian in practice but ultimately excessively "libertarian" in its ultimate aspirations. Against both totalitarianism and increasingly tyrannical versions of biotechnology, Lawler defended the indispensability of personal virtue to human happiness. It was the only path to overcoming our obsessive self-preoccupation, that sure path to unhappiness and perpetual social dislocations.

Peter was an anti-utopian thinker, a critic of technological euphoria and home-grown American forms of utopianism beginning with Walt Whitman ("The Limits of American Utopianism," July/August 2005). He saw better than almost anyone else what limitless individualism did to our capacity to 
remain faithful to others at the personal and political levels. We live in a "culture of contingency" that makes us more and more abstract "individuals" and less and less "friends, parents, children, citizens, and creatures." He believed there were thoroughly reasonable grounds for believing that we human beings are not gods and remain dependent upon a transcendent God "for our very being." In his articles and analyses, he began with the forlorn condition of modern human beings, "lost in the cosmos" as his hero Walker Percy liked to say. But like Percy and the broader Catholic intellectual tradition, Lawler believed that human speech and reason pointed to a deeper meaning at the heart of things. Peter never succumbed to existentialist despair. His post-modernism pointed to the recovery of classical reason and philosophical realism. In his view, there really is a structure to reality available through reason, revelation, and ordinary experience.

But Peter knew that he could only return to the old verities through a somewhat circuitous route. We were undergoing a "crisis of self-evidence" ("Crisis of Self-evidence," 2008). In their different ways, Locke and Darwin both taught that "there is no reality we can know that corresponds to our experiences of self, our soul, our freedom." With the Darwinians Peter affirmed that we are "social animals" although he saw human beings as much more than what Roger Scruton has called "cooperating primates." His humane Christian realism sided with Locke against Darwin in "claiming that each particular person is unique and irreplaceable" even as he affirmed "that each person is also a social or relational being." Evolution, true in itself, did not tell the whole story about human persons, nor could Locke or Darwin by themselves account for what Lawler, following Pascal, called "the greatness and misery of man." Neither scientism nor existentialism (e.g. radical moral autonomy) could do justice to the distinctiveness of the human animal who would always remain a relational person.

Peter was educated in the Straussian tradition but thought that Straussians as a whole were too skeptical of the truths of revealed religion ("What is Straussianism (According to Strauss)?," 2011). He did not believe that those dedicated to the life of the mind had to arbitrarily choose between reason and revelation or nature and history. Peter defended philosophy against postmodern nihilism and upheld deference to transcendent Reality against exaggerated appeals to the human will and to our alleged "moral autonomy." Peter Lawler was both a friend of this author and a political theorist and social critic of the first order who graced the pages of Society for almost two decades. We are grateful for his contributions. May he rest in peace.

Daniel J. Mahoney holds the Augustine Chair in Distinguished Scholarship at Assumption College where he has taught since 1986. He has been the book review editor of Society since 2000 . (dmahoney@assumption.edu) 